\title{
A new species of Eccopsis Zeller (Lepidoptera, Tortricidae) from the coastal valleys of northern Chile, with the first continental record of $E$. galapagana Razowski \& Landry
}

\author{
Héctor A. Vargas ${ }^{1}$
}

1'Departamento de Recursos Ambientales, Facultad de Ciencias Agronómicas, Universidad de Tarapacá, Casilla 6-D, Arica, Chile. havargas@uta.cl

\begin{abstract}
A new species of Eccopsis Zeller (Lepidoptera, Tortricidae) from the coastal valleys of northern Chile, with the first continental record of E. galapagana Razowski \& Landry. Eccopsis Zeller, 1852 is reported for the first time from Chile. Eccopsis razowskii Vargas, $\mathbf{n}$. sp. is described and illustrated based on specimens reared from larvae collected on native Acacia macracantha Willd. (Fabaceae) in the coastal valleys of the northern Chilean desert. Eccopsis galapagana Razowski \& Landry, 2008, previously known only from the Galapagos Islands, Ecuador, is recorded for the first time from continental South America. Larvae of the latter were collected in northern Chile feeding on Prosopis alba Griseb (Fabaceae).
\end{abstract}

KEYWORDS. Acacia macracantha; Neotropical; Olethreutini; Prosopis alba; taxonomy.

RESUMO. Uma nova espécie de Eccopsis Zeller (Lepidoptera, Tortricidae) dos valles litorais do norte do Chile, e o primeiro registro continental de E. galapagana Razowski \& Landry. Eccopsis Zeller (Lepidoptera, Tortricidae) é registrado pela primeira vez para o Chile. Eccopsis razowskii Vargas, n. sp. é descrita e ilustrada com base em espécimes criados de larvas colectadas em Acacia macracantha Willd. (Fabaceae) nos vales litorais do deserto do norte do Chile. Eccopsis galapagana Razowski \& Landry, 2008, conhecida previamente das Ilhas Galápados, Equador, é registrada pela primeira vez para SulAmérica continental. Suas larvas foram coletadas em Prosopis alba Griseb (Fabaceae).

PALAVRAS-CHAVE. Acacia macracantha; Neotropical; Olethreutini; Prosopis alba; taxonomia.

Eccopsis Zeller, 1852 is known largely from the Afrotropical Region, where it is comprised of fourteen species (Aarvik 2004; Baixeras et al. 2009). Aarvik (2004) indicated that there is a specimen identified as Eccopsis incultana (Walker, 1863) from Chile (without an abdomen) in the collection of The Natural History Museum, London. However, he stated that additional material is necessary to determine whether this species is actually present in South America. Subsequently, three Neotropical species of Eccopsis have been described from Ecuador: one from the mountains of the southern highlands (Razowski \& Wojtusiak 2008) and two from the Galapagos Islands (Razowski et al. 2008).

On the other hand, an outstanding taxonomic contribution on the fauna of Tortricidae from Chile has been recently published (Razowski \& Pelz 2010), but species of Eccopsis have been not cited. The purpose of this paper is to describe a new species of Eccopsis from the coastal valleys of the northern desert of Chile and present the first continental record of Eccopsis galapagana Razowski \& Landry, previously known only from Galapagos Islands, Ecuador.

Specimens examined were reared from larvae collected on Fabaceae trees in the Azapa, Chaca, and Lluta valleys, Arica Province, northern Chile. Vouchers are deposited in the "Museo Nacional de Historia Natural de Santiago" (MNNC), Santiago, Chile, and in the "Colección Entomológica de la Universidad de Tarapacá" (IDEA), Arica, Chile.

\section{Eccopsis galapagana Razowski \& Landry, 2008}

Eccopsis galapagana was previously known only from the Galapagos Islands, Ecuador, specifically from Floreana, Isabela, San Cristóbal, and Santa Cruz islands (Razowski et al. 2008). Thus, the specimens collected in northern Chile expand considerably the known geographic distribution of this species. Supposed evolutionary relationships among the moth fauna of the Galapagos Islands and the northern desert of Chile have been already suggested for other moth families, with pairs of morphologically similar species represented by one species restricted to the Galapagos Islands and the other distributed in northern Chile (e.g., Vargas 2003; Vargas \& Parra 2004). In the case of Eccopsis galapagana, the same species is shared by both geographic areas.

The specimens from Chile were reared from leaf-tying larvae on Prosopis alba Griseb (Fabaceae), which represents the first recorded hostplant for E. galapagana. Hostplant records for two African species of Eccopsis are in the families Anacardiaceae, Euphorbiaceae, and Sterculiaceae (Aarvik 2004). Thus, this is the first record of Fabaceae as a larval host for Eccopsis.

The identification of E. galapagana was based on comparisons with original descriptions and figures in Razowski et al. (2008) and photographs of the male and female genitalia of paratypes of E. galapagana provided by Bernard 
Landry, "Muséum d'histoire naturelle de Genève", Geneva, Switzerland.

Examined material. CHILE, Arica: 2 males, 2 females, Lluta, Arica, Chile, October 2003, H.A. Vargas coll.//reared from larva on Prosopis alba; 1 male, Lluta, Arica, Chile, August 2010, H.A. Vargas coll.//reared from larva on Prosopis alba, July 2010; 2 males, 1 female, Lluta, Arica, Chile, October 2010, H.A. Vargas coll.//reared from larva on Prosopis alba, September 2010 (IDEA); 2 males, 2 females, same data (MNNC).

\section{Eccopsis razowskii Vargas, sp. nov.}

(Figs. 1-3)

Diagnosis. The wing pattern and genitalia of the new species are similar to E. galapagana, but the two are easily separated by features of the male and female genitalia. Many short straight spines and a single strong, curved spine are present at terminal part of the right sacculus and near of the dorsal margin of the left sacculus of E. razowskii, but these are absent in E. galapagana. Many short spines and one long, curved spine are present on the terminal part of the left sacculus of E. galapagana, but these are absent in E. razowskii. The sterigma is a broad, well sclerotized ring in the female genitalia of E. razowskii, whereas it forms a pair of large lobes in E. galapagana.

Description. Male (Fig. 1). Head: Mostly reddish brown, vertex covered by elongate reddish brown scales with cleft apex, dorsal area of the front similar to vertex, ventral area covered by short whitish brown scales, occiput with elongate reddish brown scales; antenna filiform, scape and pedicel reddish brown, flagellomeres with dorsal surface with greyish brown scales, ventral surface ciliate; labial palpus slightly upturned, length near two times compound eye diameter, first palpomere whitish brown, second palpomere with elongated reddish brown scales, third palpomere with reddish brown scales. Thorax: Reddish brown dorsally, pale whitish brown laterally; foreleg greyish brown with some light whitish grey scales scattered; midleg similar to foreleg, but with a pair of pale whitish grey tibial spurs; hindleg pale whitish grey, with two pairs of tibial spurs. Forewing: length 4.9-6 mm; mostly pale reddish brown with some greyish brown and white-tipped scales scattered, median fascia dark reddish brown, reaching the discal cell, postmetian fascia reaching the posterior portion of the termen; fringe mostly reddish brown on the termen, dark reddish brown where the postmedian fascia meets the termen; also dark reddish brown on apex and tornus. Hindwing pale whitish grey with concolours fringe. Abdomen: Pale whitish grey. Male genitalia (Fig. 2) with tegumen straight; uncus relatively short, elongate, broadened distally, apex slightly excavated, apical ventral surface with 5-10 short spines; socii drooping, hairy, length similar to uncus, rounded terminally; saccus straight, U-shaped; valvae asymmetrical, without basal lobes; right valva: sacculus with ventral margin with many long spine-like setae along distal half, a distal lobe armed with many short, right spines and one strong, curved spine, cucullus with distal margin broadly rounded, dorsal margin slightly concave, ventral margin concave distally, internal surface densely covered by short spine-like setae; left valva: sacculus with ventral margin with many long spine-like setae along distal half, more dense at distal lobe, a group of many short, straight spines and one strong, curved spine near to the dorsal margin, cucullus with distal margin broadly rounded, dorsal margin sligthtly concave, basal half of the ventral margin concave, internal surface densely covered by short spine-like setae; phallus short, strongly curved.

Female. General habitus similar to male. Forewing: length 5-6 mm. Female genitalia (Fig. 3): sterigma as a broad, well sclerotized ring; antrum slightly sclerotized, long, rest of the ductus bursae membranous, short, sinuous; ductus seminalis arising at basis of the membranous portion of the ductus bursae; corpus bursae membranous, spherical; signum ventrally in the corpus bursae, half-moon-shaped, with three-five plain processes with round apex.

Type material. Male holotype CHILE, Arica: Chaca, Arica, Chile, June 2004, H.A. Vargas coll., ex. larva on leaves of Acacia macracantha (MNNC). Paratypes CHILE, Arica: 2 males, 3 females, same data as holotype (MNNC); 1 male, Azapa, Arica, Chile, July 2004, H.A. Vargas coll., ex. larva on leaves of Acacia macracantha, 1 male, Azapa, Arica, Chile, June 2008, H.A. Vargas coll., ex. larva on leaves of Acacia macracantha (IDEA).

Etymology. Eccopsis razowskii is dedicated to Dr. Józef Razowski, honring his outstanding contributions to the systematics of Tortricidae.

Hostplant. The specimens studied were reared from leaftying larvae on Acacia macracantha Willd. (Fabaceae).

Geographic distribution. Eccopsis razowskii has been collected only in the Azapa and Chaca Valleys, coastal desert of northern Chile.

Remarks. Eccopsis razowskii is the first species in the genus described from Chile. The absence of basal lobes of the valvae is shared with two other Neotropical species, Eccopsis floreana Razowski \& Landry, 2008 and E. galapagana. Thus, the character state may represent a synapomorphy for Neotropical members of the genus. However, the male of another Neotropical species, Eccopsis eltundana Razowski \& Wojtusiak, 2008, remains unknown (Razowski \& Wojtusiak 2008). Presence of basal lobes is shared by all African Eccopsis, even though basal lobes are strongly reduced in the male genitalia of the type-species, $E$. wahlbergiana Zeller, 1852 (Aarvik 2004).

The association of the larvae of E. galapagana and $E$. razowskii with Fabaceae also is novel to the Neotropics. Apparently, Fabaceae are important hostplants for larvae of native tortricids in northern Chile; this relationship was previously reported from this area by Clarke (1987), Vargas (2006, 2007), and Vargas \& Parra (2006).

\section{ACKNOWLEDGEMENTS}

The author thanks Bernard Landry for kindly providing literature and photographs of the genitalia of paratypes of $E$. 

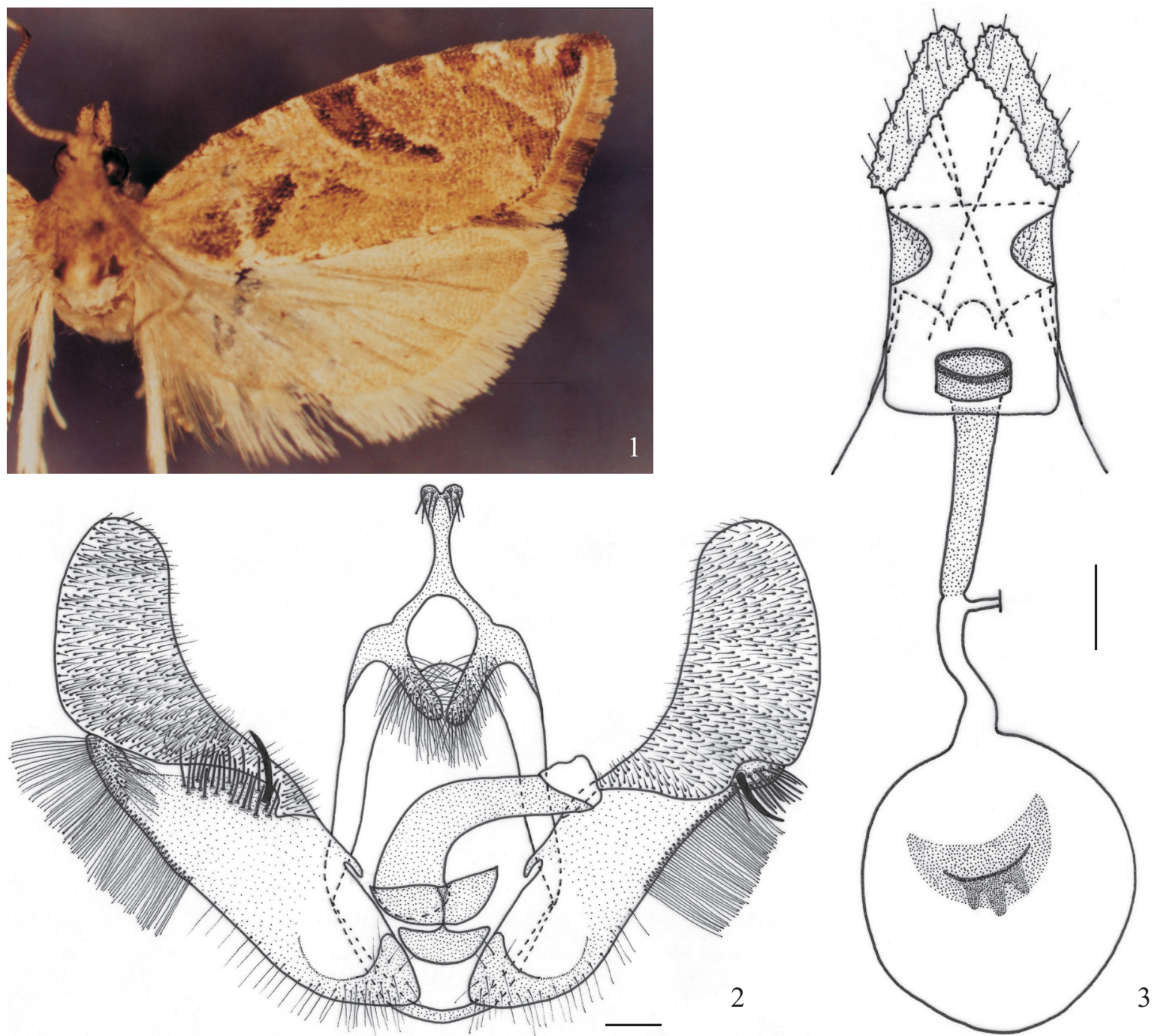

Figs. 1-3. Eccopsis razowskii sp. nov.: 1, male holotype, dorsal view; 2, male genitalia, ventral view; 3 , female genitalia, ventral view. Scale bars: $2=0.1$ $\mathrm{mm}, 3=0.2 \mathrm{~mm}$.

galapagana; Leif Aarvik for providing literature; and two anonymous referees for kind comments and suggestions on a preliminary version. This study was supported by project DIEXA-UTA 9710-10.

\section{REFERENCES}

Aarvik, L. 2004. Revision of the subtribe Neopotamiae (Lepidoptera: Tortricidae) in Africa. Norwegian Journal of Entomology 51: 71-122. Baixeras, J.; J. W. Brown \& T. M. Gilligan. 2009. T@RTS: Online World Catalogue of the Tortricidae (Version 1.3.1). Available from: http:// www.tortricidae.com/catalogue.asp (accessed 8 November 2010).

Clarke, J. F. G. 1987. Two new species of Cryptophlebia Walsingham (Lepidoptera: Tortricidae) from Chile. Acta Entomológica Chilena 14: 7-12.

Razowsky, J. \& V. Pelz. 2010. Tortricidae from Chile (Lepidoptera: Tortricidae). SHILAP Revista de Lepidopterología 38: 5-55.

Razowski, J.; B. Landry \& L. Roque-Albelo. 2008. The Tortricidae (Lepidoptera) of the Galapagos Islands, Ecuador. Revue Suisse de Zoologie 115: $185-220$.
Razowski, J. \& J. Wojtusiak. 2008. Tortricidae (Lepidoptera) from the mountains of Ecuador. Part 1: Southern Higlands. Acta Zoologica Cracoviensa 51B: $7-41$.

Vargas, H. A. 2003. Una nueva especie de Periploca Braun (Lepidoptera: Cosmopterigidae) de Chile. Acta Entomológica Chilena 27: 61-65.

Vargas, H. A. 2006. Descripción de la larva de último instar y de la pupa de Cryptophlebia cortesi Clarke (Lepidoptera: Tortricidae). Neotropical Entomology 53: 338-343.

Vargas, H. A. 2007. Descripción de la larva de último instar y de la pupa de Cydia largo Heppner (Lepidoptera, Tortricidae). Revista Brasileira de Entomologia 51: 263-266.

Vargas, H. A, \& L. E. Parra. 2004. Una nueva especie de Eupithecia Curtis (Lepidoptera: Geometridae) del extremo norte de Chile. Revista Chilena de Historia Natural 77: 485-490.

Vargas, H. A. \& L. E. Parra. 2006. Nuevos registros de distribución y notas biológicas de Cydia largo Heppner (Lepidoptera: Tortricidae). Gayana 70: 293-294.

Received 9/11/2010; accepted 19/4/2011

Editor: Marcelo Duarte 